\title{
The Commercial Exploitation Continuum
}

\author{
Phillip W. Goter*
}

\section{INTRODUCTION}

In the realm of patent validity, patentable subject matter and obviousness seem to be perennially en vogue. Academics, courts, and practitioners alike dwell on these areas because they lend themselves well to legal scholarship and debate. Patent law courses naturally gravitate towards discussion of seminal cases such as KSR Int'l Co. v. Teleflex Inc. ${ }^{1}$ and Bilski v. Kappos. ${ }^{2}$ Less often do courses delve into detailed discussion of the greater issues involving $\S 102(\mathrm{~b})$ and its on-sale and publicuse bars ${ }^{3}$ - even though application of either of these statutory bars results in an absolute bar to patentability, invalidating a granted patent. However, the greater issues-including an articulate definition of commercial exploitation as a predominant factor in identifying whether an invention was in public use or on sale-are of extreme importance to innovators and those advising them, who seek to maximize their effective patent lifetime by aligning the market window, product launch, and patent filing. Considering parties litigate the issue of patent validity almost as frequently as infringement, ${ }^{4}$ one would expect more discussion of the absence of a cohesive approach to application of the public-use and on-sale bars with respect to

(C) 2012 Phillip W. Goter

* The author is an attorney at the law firm of Fish \& Richardson, P.C. where he focuses on patent litigation matters. J.D., The University of Iowa College of Law, 2011; M.B.A., The University of Iowa Tippie School of Management, 2008; M.S., The University of North Dakota, 2005; B.S., The University of North Dakota, 2001. The author would like to thank Andrew Dommer for his constructive critique.

1. KSR Int'l Co. v. Teleflex Inc., 550 U.S. 398 (2007) (concerning obviousness).

2. Bilski v. Kappos, 130 S. Ct. 3218 (2010) (concerning patentable subject matter)

3. Patents, 35 U.S.C. $§ 102$ (2006).

4. Kimberly A. Moore, Judges, Juries, and Patent Cases-An Empirical Peek Inside the Black Box, 99 MicH. L. REV. 365, 390 (2000). 
commercialization and commercial exploitation.

Contrary to the commercial interests of innovators, $\S$ 102(b) of the Patent Act "encourages an inventor to enter the patent system promptly" by defining separate statutory bars to patentability that prohibit sales and public uses of an invention more than a year prior to filing a patent application. ${ }^{5}$ To determine public use, the Federal Circuit currently asks whether the invention was accessible to the public or commercially exploited. ${ }^{6}$ As for determining whether an invention was on sale, the test is whether there was a commercial offer for sale after the invention was ready for patenting. ${ }^{7}$

As the Federal Circuit's jurisprudence currently stands, the commercial-exploitation prong of the public-use bar lacks any coherent definition and is dangerously close to subsumption by the on-sale bar. Take, for example, the Federal Circuit's Invitrogen Corp. v. Biocrest Manufacturing decision, in which it noted that "[c]ommercial exploitation is a clear indication of public use, but it likely requires more than . . . a secret offer for sale."8 Consider further the Federal Circuit's TP Laboratories, Inc. $v$. Professional Positioners, Inc. decision that linked "commercial exploitation" with commercial sale of the invention-as opposed to sale for experimental purposes. ${ }^{9}$ Finally, in Atlanta Attachment Co. v. Leggett \& Platt, Inc., the Federal Circuit determined "[a]n offer to mass produce production models . . . is commercial exploitation." 10 This may just be careless wording resulting in conflation of commercial exploitation with being "on sale," but the specter of commercial exploitation continues to loom as a distinct, principal criterion for satisfying the "public use" prong of the $\S 102$ bar. As such, it deserves a definition.

With the passage of the America Invents Act (AIA), the

5. Woodland Trust v. Flowertree Nursery, Inc., 148 F.3d 1368, 1370 (Fed. Cir. 1998). Section 102(b) conditions patentability upon the invention not being "patented or described in a printed publication in this or a foreign country or in public use or on sale in this country, more than one year prior to the date of the application for patent in the United States.” 35 U.S.C. § 102(b).

6. Am. Seating Co. v. USSC Grp., 514 F.3d 1262, 1267 (Fed. Cir. 2008) (citing Invitrogen Corp. v. Biocrest Mfg., 424 F.3d 1374, 1380 (Fed. Cir. 2005)).

7. Invitrogen Corp., 424 F.3d at 1379.

8. Id. at 1380 .

9. TP Labs., Inc. v. Prof'l Positioners, Inc., 724 F.2d 965, 972-73 (Fed. Cir. 1984).

10. Atlanta Attachment Co. v. Leggett \& Platt, Inc., 516 F.3d 1361, 1366 (Fed. Cir. 2008). 
United States converted itself to a first-to-file priority-of-right system with significant changes to $\S 102 .{ }^{11}$ However, the relevant changes under the AIA apply only prospectively to patents issued on or after September 16, 2012.12 This leaves at least twenty more years during which patents could be litigated under the existing standard. Under $\$ 102$ currently, an inventor is entitled to a patent unless "the invention was patented or described in a printed publication in this or a foreign country or in public use or on sale in this country, more than one year prior to the date of the application for patent in the United States."13 In contrast, AIA allows an inventor a patent unless "the claimed invention was patented, described in a printed publication, or in public use, on sale, or otherwise available to the public before the effective filing date of the claimed invention." 14 Note that the AIA does not relieve inventors of the onsale or public-use bars currently existing in $§ 102(b)$, and so there is no reason to expect a radical departure from existing $\S 102(\mathrm{~b})$ precedent as courts begin to consider whether to apply the same bars - now residing in $\S 102(a)$ - to patents facing validity challenges under the AIA. If anything, these cases may arise more frequently given the expansion of prior-user rights and the concern that they will encourage covert innovation and use. ${ }^{15}$

To date, perhaps courts have not seen the appropriate set of facts, at the appropriate stage of the proceedings, to decisively clarify the issue. Take for instance an agri-tech company that creates a drought-tolerant hybrid seed that exhibits resistance only to a new, environmentally safe pesticide. No doubt the company will want to patent this variation, but when will it apply for the patent? In order to commercially market the seed, application of the pesticide to the seed must receive

11. Leahy-Smith America Invents Act, sec. 3(b)(1), 125 Stat. 284 (2011) (amending 35 U.S.C. § 102).

12. Id. at sec. 35 .

13. Patents, 35 U.S.C. $\S 102(b)$ (2006).

14. Leahy-Smith America Invents Act, sec. 3(b)(1).

15. See America Invents Act: Hearing Before the Subcomm. on Intellectual Prop., Competition, and the Internet of the H. Comm. on the Judiciary, 112th Cong. 50 (2011) (statement of Rep. Sensenbrenner, Member, H. Comm. on the Judiciary) ("[E]xpanding prior user rights will harm inventors who share their knowledge and discovery and reward those who choose to stay silent, keep innovation secret, and don't contribute to the products of science . . . [by] effectively put[ting] trade secrecy in the patent law with a powerful incentive-a royalty-free statutory license."). 
regulatory approval. Obtaining this approval requires gathering field data. So, the company confidentially, and subject to its control, plants the seed, applies the pesticide, and gathers the data. These actions do not fall under the usual prong of public use, but if the activities are performed solely with a view to commercialization of the invention, is it commercial exploitation? 16

As a second example, suppose a software company develops source-control and change-control tools, representing a major paradigm shift from existing tools, and uses them internally for five years during the development of its next-generation operating system. The company wants to patent the tools and market them because it has received accolades for the softwareengineering revolution sparked by the developmental success and resulting stability of its operating system. As we will see, use of the tools did not result in creation of the operating system in the same way that practicing a process to manufacture products does, and so it is unlikely that this example would fall under existing caselaw finding public use through public accessibility. ${ }^{17}$ But, is it commercial exploitation to utilize the software-engineering management tools to produce software that is commercially marketed?

This Article addresses the abject lack of a meaningful definition of "commercial exploitation"-apart from being on saleas a prong of the test for public use. First, this Article introduces the Federal Circuit's on-sale bar jurisprudence. Second, this Article discusses the public-use bar and its experimental-use exception while attempting to delineate between the two separate bars. In examining the interplay between the commercialexploitation prong of the public-use bar and the on-sale bar, relevant Supreme Court decisions and recent district court decisions are also discussed. Finally, this Article concludes by ex-

16. The answer is likely yes, due to language elsewhere in the Patent Act, but these facts have not yet come before a court. See 35 U.S.C. $\S 273($ a)(1) (2006) ("[T]he subject matter for which commercial marketing or use is subject to a premarketing regulatory review period during which the safety or efficacy of the subject matter is established, including any period specified in section 156(g), shall be deemed 'commercially used' and in 'commercial use' during such regulatory review period ....") But, is "commercial use" the same as "commercial exploitation"?

17. Note that in this example, a computer-aided software engineering tool may arguably "produce" the software product, therefore the example points to the tools used to manage the development process. 
amining circumstances found relevant to a determination of commercial exploitation.

\section{THE ON-SALE BAR}

To fully appreciate the current ambiguity surrounding the public-use bar, one must first consider the Federal Circuit's decisions regarding the on-sale bar. One district court acknowledged that "there are differences in the analysis of the two bars: the public-use bar focuses on the public's reliance on an invention that is thought to be in the public domain, while the on-sale bar centers on any commercialization beyond the one year grace period." 18 Even so, the Federal Circuit has yet to articulate a substantive difference between "commercial exploitation" as applied to the "on-sale" and "public-use" bars. Indeed, "[m]any decisions consider Section 102(b) without carefully differentiating public use and on sale .... However, it is clear that public use and on sale are separate events and one may occur without the other."19

Section 102(b) bars patentability for inventions that were "on sale in this country, more than one year prior to the date of the application for patent in the United States." 20 In addition to "a policy favoring prompt and widespread disclosure of inventions to the public," the Federal Circuit has identified other policies underlying the on-sale bar, including "a policy against removing inventions from the public domain which the public justifiably comes to believe are freely available due to commercialization ... [and] a policy of giving the inventor a reasonable amount of time following sales activity to determine whether a patent is worthwhile." 21

In Pfaff $v$. Wells Electronics, Inc., the Supreme Court defined the baseline test for determining whether the on-sale bar applies. ${ }^{22}$ "[T] $]$ he on-sale bar applies when two conditions are satisfied before the critical date. First, the product must be the subject of a commercial offer for sale .... [and s] econd, the invention must be ready for patenting." 23 This Article discusses

18. Honeywell Int'l, Inc. v. Universal Avionics Sys. Corp., 343 F. Supp. 2d 272, 290 (D. Del. 2004).

19. 2-6 DONALD S. CHISUM, CHISUM ON PATENTS § 6.02[6] (2010).

20. Patents, 35 U.S.C. § 102(b) (2006).

21. In re Caveney, 761 F.2d 671, 676 (Fed. Cir. 1985).

22. Pfaff v. Wells Elecs. Inc., 525 U.S. 55, 67 (1998).

23. Id.; see also Preemption Devices, Inc. v. Minn. Mining \& Mfg. Co., 732 F.2d 903, 905-06 (Fed. Cir. 1984) (defining the "critical date" as the date one 
each of these prongs below.

\section{A. Subject OF A COMMERCIAL OFFER For SALE}

The first prong of the on-sale bar requires a commercial offer for sale or an actual sale. This trigger creates little hardship for patentees because, as the Court noted, "[a]n inventor can both understand and control the timing of the first commercial marketing of his invention." 24 Prior to Pfaff, the Federal Circuit applied a totality-of-the-circumstances test to determine whether a "substantially complete" invention was on sale prior to the critical date - the date one year prior to application for a patent. ${ }^{25}$ Although not the issue before it in Pfaff, the Supreme Court criticized the Federal Circuit's totality-of-thecircumstances approach to "determin[ing] the trigger for the on-sale bar" in dicta. ${ }^{26}$ "While the Supreme Court has not explained what is necessary for a 'commercial offer for sale,' [the Federal Circuit] ha[s] held that two elements are necessary." 27 First, there must be a "commercial offer" and second, the "offer [must be] for the patented invention." 28

\section{A Commercial Offer}

Noting "the importance of having a uniform national rule regarding the on-sale bar," the Federal Circuit has held that determining whether a commercial offer for sale was made is a matter of Federal Circuit law, "to be analyzed under the law of contracts as generally understood." 29 Thus, the Federal Circuit looked to the Uniform Commercial Code (UCC) and the Restatement of Contracts to define a "commercial offer for sale." 30

year prior to the patent application having been filed).

24. Pfaff, 525 U.S. at 67.

25. Seal-Flex, Inc. v. Athletic Track \& Court Constr., 98 F.3d 1318, 1323 n.2 (Fed. Cir. 1996).

26. Pfaff, 525 U.S. at 66 n.11 (noting that the test "has been criticized as unnecessarily vague") (citing Seal-Flex, 98 F.3d at 1323 n.2).

27. Sparton Corp. v. United States, 399 F.3d 1321, 1323 (Fed. Cir. 2005).

28. Id. (citing Scaltech, Inc. v. Retec/Tetra, L.L.C., 269 F.3d 1321, 1328 (Fed. Cir. 2001)).

29. Grp. One, Ltd. v. Hallmark Cards, Inc., 254 F.3d 1041, 1047 (Fed. Cir. 2001) (noting that any alternative holding would mean that a patent could simultaneously be valid in some jurisdictions, but not others-which "is clearly incompatible with a uniform national patent system").

30. Id. at 1047-48 (citing Enercon GmbH v. Int'l Trade Comm'n, 151 F.3d 1376, 1382 (Fed. Cir. 1998)) (noting that "[t]he UCC has been recognized as 
The Federal Circuit has noted that "[n]either profit, revenue, nor even an actual sale is required for the use to be a commercial offer under section 102(b)." ${ }_{11}$ In order to constitute an offer for sale under $\S 102(b)$, an offer must be one "which the other party could make into a binding contract by simple acceptance (assuming consideration)." 32

In contrast, communications attempting to "generate interest" in an invention, by inviting discussion of licensing terms ${ }^{33}$ or merely "[q]uot[ing] . . . a sales price to a potential distributor of a product that is not available for sale and distribution," do not alone constitute commercial offers for sale. ${ }^{34}$ "[T]here must be more than an informational exchange of price information .. .." 35 Note that actually producing or delivering a commercial good is not required. 36 Likewise, performance of the patented method prior to the critical date is not required so long as the commercial offer for sale occurred prior to the critical date. ${ }^{37}$

Once someone - the inventor, his supplier or any other third party-places an invention on sale, the on-sale bar is implicated. 38 Thus, "even if a thief 'stole' the claimed invention and passed it on to an innocent buyer, the innocent buyer's subsequent offer to sell still trigger[s] the plain language of the on-sale bar" because an inventor could easily protect himself by

the general law governing the sale of goods" and that Supreme Court decisions support consulting the UCC and Restatement "in the commercial contract law context").

31. Atlanta Attachment Co. v. Leggett \& Platt, Inc., 516 F.3d 1361, 1365 (Fed. Cir. 2008).

32. Grp. One, Ltd., 254 F.3d at 1048.

33. Id. at 1049 .

34. C.R. Bard, Inc. v. M3 Sys., Inc., 157 F.3d 1340, 1357 (Fed. Cir. 1998).

35. Id.

36. Atlanta Attachment, 516 F.3d at 1365 (finding that even though a prototype embodying the invention was never delivered, it was sold where the manufacturer sent "an invoice for the machine (an offer), and [the client] paid for the machine (an acceptance)"); see also Evans Cooling Sys., Inc. v. Gen. Motors Corp., 125 F.3d 1448, 1452 (Fed. Cir. 1997) (finding that where an independent car dealership violated internal procedures by offering the 1992 Corvette for sale prior to GM's model announcement, "the mere fact that the offer for sale was illegal or ineffective does not remove it from the purview of the section 102(b) bar ... . [even if] the contract was cancelable or changeable under certain circumstances").

37. Plumtree Software, Inc. v. Datamize, L.L.C., 473 F.3d 1152, 1162 (Fed. Cir. 2006)

38. Special Devices, Inc. v. OEA, Inc., 270 F.3d 1353, 1355 (Fed. Cir. 2001) (noting that "the text of section 102(b) itself makes no room for a 'supplier' exception"). 
promptly "filing a patent application within the one-year deadline." 39 Underlying such a result is the "primary policy" of the on-sale bar namely, encouraging inventors "to enter the patent system promptly." 40 Thus, an inventor's own prior, secret commercial use implicates the statutory bar, ${ }^{41}$ as do secret "sales for the purpose of the commercial stockpiling of an invention." 42

Generally, the on-sale bar precludes patenting a process that the patentee has actually used-overtly or covertly-to produce a commercialized product. 43 "In contrast, if the product were sold by one other than the patentee, and the process of making remained unknown, then sale of the product would not pose a statutory bar to a claim on the process." 44 Notice we already encounter commingling of the separate on-sale and public-use bars-in Woodland Trust, the irrigation system was never alleged to be "on sale" but rather was challenged as in public use because it was allegedly used to preserve the flora offered for sale at several greenhouses. ${ }^{45}$ Of course, performing a process for consideration would likewise trigger the on-sale bar. ${ }^{46}$

39. Id.

40. Id. at 1357 (quoting Woodland Trust v. Flowertree Nursery, Inc., 148 F.3d 1368, 1370 (Fed. Cir. 1998)); see also In re Caveney, 761 F.2d 671, 676 (Fed. Cir. 1985) (noting that the on-sale bar is intended to promote "prompt and widespread disclosure of inventions to the public").

41. Woodland Trust, 148 F.3d at 1370.

42. Special Devices, Inc., 270 F.3d at 1357 (finding the patentee's contract "to have the patent's commercial embodiment mass-produced more than one year before it filed a patent application" implicated the on-sale bar).

43. In re Kollar, 286 F.3d 1326, 1333 (Fed. Cir. 2002) (“[T]he issue concerning the on-sale bar is not whether the process is physically represented or enabled by a written description, but whether the process has been commercialized."); see D.L. Auld Co. v. Chroma Graphics Corp., 714 F.2d 1144, 114748 (Fed. Cir. 1983) (finding that a pre-critical-date offer to sell a device, produced using the patented method, invalidated the patent).

44. TorPharm, Inc. v. Ranbaxy Pharms., Inc., 336 F.3d 1322, 1327 (Fed. Cir. 2003) (comparing D.L. Auld, 714 F.2d at 1147-48); see also W.L. Gore \& Assocs., Inc. v. Garlock, Inc., 721 F.2d 1540, 1550 (Fed. Cir. 1983) ("As between a prior inventor who benefits from a process by selling its product but suppresses, conceals, or otherwise keeps the process from the public, and a later inventor who promptly files a patent application from which the public will gain a disclosure of the process, the law favors the latter."); Palmer v. Dudzik, 481 F.2d 1377, 1385-86 (C.C.P.A. 1973) (finding that the inventor had concealed his invention since he kept his method secret and the products did not teach the public anything about the secret method).

45. Woodland Trust, 148 F.3d at 1369-70.

46. Compare Scaltech, Inc. v. Retec/Tetra, L.L.C., 269 F.3d 1321, 1328 
In a case arising under the on-sale bar, the Federal Circuit considered whether an offer to practice a patented method to produce an output - the output to be provided to a third party in return for a commercial benefit-invalidated the method claim. ${ }^{47}$ The court determined that the on-sale bar applies to the secret use of software to generate an output that is subject to an offer for sale, even if the output is not patented. 48

Finally, the Federal Circuit requires that "a sale or offer to sell under . . . $102(\mathrm{~b})$ must be between two separate entities." 49 Whether two entities are in fact separate "depends on whether the seller so controls the purchaser that the invention remains out of the public's hands." 50 The Federal Circuit has found a lack of common control, and thus separate entities, where a single government entity simply provided funding to a number of research institutions. ${ }^{51}$ Other factors to consider in determining whether two entities are separate include "the proportion of outstanding shares [of the company] held by the various parties; [the allegedly common entity's] ability to control critical materials and products; and the terms of the Operator's [sic] and Shareholder's agreements."52 Factors that are insufficient to demonstrate the existence of a common entity, include an unrelated requirement of mutual consent to management-employment decisions, a requirement that a distributor "use its best efforts to sell and service" products and not sell competing products, and a confidentiality obligation protecting one entity's research and development information. 53

(Fed. Cir. 2001) (invalidating a claim to a method for treating oil-refinery waste) with In re Kollar, 286 F.3d at 1333 (refusing to apply the on-sale bar to licensing of an invention "under which development of the claimed process would have to occur before the process is successfully commercialized").

47. Plumtree Software, Inc. v. Datamize, L.L.C., 473 F.3d 1152, 1162 (Fed. Cir. 2006).

48. Id.

49. In re Caveney, 761 F.2d 671, 676 (Fed. Cir. 1985).

50. Ferag AG v. Quipp, Inc., 45 F.3d 1562, 1567 (Fed. Cir. 1995).

51. Netscape Commc'ns Corp. v. Konrad, 295 F.3d 1315, 1324 (Fed. Cir. 2002) (finding that the Department of Energy "never exercised such control over [the research labs at Berkeley, Stanford, and the Super Collider], as to render all part of the same entity," and thus a sale of an invention between two of the entities implicated the on-sale bar).

52. Ferag AG, 45 F.3d at 1567 ("Because [Entity A] could not control [Entity B's] marketing of the invention, the two companies were separate entities for section 102(b) purposes and the transaction between them gives rise to a statutory bar.").

53. Id. (finding that "complete management authority over the operations . . . constrained only by a mutual consent clause mandating agreement . . . for 


\section{Offer for the Patented Invention}

According to the Federal Circuit, "[w]hen the asserted basis of invalidity is a public use or on-sale bar, the court should determine "whether the subject of the barring activity met each of the limitations of the claim, and thus was an embodiment of the claimed invention." 54 The Federal Circuit has held that this step "involves a comparison of the asserted claims with the device or process that was sold." 55 When "each and every limitation [of the claimed invention is] found either expressly or inherently" in the product that was sold, the claim is anticipated. ${ }^{56}$

In the case of a license to practice a process that contemplates sale of the products manufactured using the claimed process, the Federal Circuit held that such an agreement did not offer for sale the product of the claimed process. ${ }^{57}$ When the license pertains to patent rights, the on-sale bar will not be implicated. 58 But, where the process has been carried out or performed as a result of the transaction, the on-sale bar may be implicated. ${ }^{59}$

\section{B. READY FOR PATENTING}

In Pfaff, the Supreme Court considered the issue of whether the on-sale bar is implicated when an invention is "on sale" but "has not yet been reduced to practice" (e.g., the item has not actually been made or the process has not actually been per-

certain corporate decisions" is insufficient to demonstrate common control and a single entity).

54. Dana Corp. v. Am. Axle \& Mfg., 279 F.3d 1372, 1375 (Fed. Cir. 2002) (quoting Scaltech Inc. v. Retec/Tetra, L.L.C., 178 F.3d 1378, 1383 (Fed. Cir. 1999)).

55. Minton v. Nat'l Ass'n of Sec. Dealers, 336 F.3d 1373, 1376 (Fed. Cir. 2003).

56. Celeritas Techs. Ltd. v. Rockwell Int'l Corp., 150 F.3d 1354, 1361 (Fed. Cir. 1998).

57. In re Kollar, 286 F.3d 1326, 1330-31 (Fed. Cir. 2002); see MasHamilton Grp. v. LaGard, Inc., 156 F.3d 1206, 1217 (Fed. Cir. 1998) (finding that conveyance of production rights or exclusive marketing rights did not constitute a sale); Moleculon Research Corp. v. CBS, Inc., 793 F.2d 1261, 1267 (Fed. Cir. 1986) (holding that "an assignment or sale of the rights in the invention and potential patent rights is not a sale").

58. In re Kollar, 286 F.3d at 1330 n.3 ("[A] 'license' that merely grants rights under a patent cannot per se trigger the application of the on-sale bar.").

59. See id. at 1332 . 
formed). 60 The Court determined that for the on-sale bar to arise, the invention must be "ready for patenting." 61 This may be shown "by proof of reduction to practice before the critical date; or by proof that prior to the critical date the inventor had prepared drawings or other descriptions of the invention that were sufficiently specific to enable a person skilled in the art to practice the invention."62 In arriving at this standard, the Supreme Court rejected an alternative suggested by the Solicitor General: "[I]f the sale or offer in question embodies the invention for which a patent is later sought, a sale or offer to sell that is primarily for commercial purposes and that occurs more than one year before the application renders the invention unpatentable." 63 It is also important to note at the outset that the invention must at least be conceived of prior to any offer for sale because "[w]ith no conception of an invention, there cannot be an offer for sale or a sale of that invention."64

Reduction to practice of an invention occurs when an embodiment "meets every limitation and operates for its intended purpose." 65 "An invention works for its intended purpose when there is a demonstration of the workability or utility of the claimed invention." 66 While "an inventor is entitled to perfect

60. Pfaff v. Wells Elecs., Inc., 525 U.S. 55, 55 (1998).

61. Id. at 66 .

62. Id at 67-68 (noting that "the second condition of the on-sale bar is satisfied because the drawings Pfaff sent to the manufacturer before the critical date fully disclosed the invention"); see also Robotic Vision Sys., Inc. v. View Eng'g, Inc., 249 F.3d 1307, 1313 (Fed. Cir. 2001) (“[T] he test for determining whether [an] invention is complete also requires proof that the invention was enabled prior to the critical date.").

63. Pfaff, 525 U.S. at 68 n.14 (quoting Seal-Flex, Inc. v. Athletic Track \& Court Constr., 98 F.3d 1318, 1325 (Fed. Cir. 1996) (Bryson, J., concurring in part and concurring in the result) (internal quotation marks omitted) (explaining that this formulation does not account for "additional development after the offer for sale")).

64. Sparton Corp. v. United States, 399 F.3d 1321, 1325 (Fed. Cir. 2005) (finding no conception prior to the offer for sale and thus no on-sale bar). Compare id. at 1324-25, with Robotic Vision Sys., Inc., 249 F.3d at 1313 (finding that conception, followed by offer for sale, followed by enabling internal disclosure triggers the on-sale bar).

65. Honeywell Int'l, Inc. v. Universal Avionics Sys. Corp., 488 F.3d 982, 997 (Fed. Cir. 2007) (citing Eaton v. Evans, 204 F.3d 1094, 1097 (Fed. Cir. 2000)).

66. Id. (citing Fujikawa v. Wattanasin, 93 F.3d 1559, 1563 (Fed. Cir. 1996)); see Robotic Vision Sys., Inc., 249 F.3d at 1313 (finding that an earlier commercial offer for sale, when combined with a subsequent, internal enabling disclosure may trigger the on-sale bar even though there was no proof that the conceived-of invention was ready for patenting at the time of the offer for sale); 
claimed features as part of reducing the invention to practice,"67 once the invention is workable or useful "an invention can be considered reduced to practice "even though it may later be refined or improved."'68

Like the public-use bar, the on-sale bar contains an experimental-use exception which is unavailable where a commercial offer for sale has been made. ${ }^{69}$ The Federal Circuit applies the experimental-use doctrine to the ready-for-patenting prong of the on-sale bar and notes that there is "overlap" of the proofs required for experimental use and ready for patenting. ${ }^{70}$ " $[\mathrm{H}]$ owever, the Supreme Court explicitly preserved proof of experimentation as a negation of statutory bars." 71 For instance, tests conducted to determine whether an invention worked for its intended purpose are not "demonstrations" of workability or utility when the tests are part of an effort to reduce the invention to practice and work remains "to ascertain the success of the operation."72 This is especially the case where

see also Cygnus Telecomms. Tech., L.L.C. v. Telesys Commc'ns, L.L.C. (In re Cygnus Telecomms. Tech., L.L.C., Patent Litig.), 536 F.3d 1343, 1355 (Fed. Cir. 2008) ("The question whether [a] system would work on a commercial scale is distinct from whether the system embodied the claims in the [ patents at issue.").

67. Atlanta Attachment Co. v. Leggett \& Platt, Inc., 516 F.3d 1361, 1367 (Fed. Cir. 2008) (citing Electromotive Div. of Gen. Motors Corp. v. Transp. Sys. Div. of Gen. Electric Co., 417 F.3d 1203, 1211 (Fed. Cir. 2005)).

68. Id. (quoting New Railhead Mfg. L.L.C. v. Vermeer Mfg. Co., 298 F.3d 1290, 1297 (Fed. Cir. 2002)) (finding that a third prototype worked for its intended purpose and was thus reduced to practice and ready for patenting even though the inventor conducted further testing, refunded the cost of the third prototype, and responded to suggestions resulting in production of a fourth prototype, closer to a commercial-ready product).

69. Id. at 1366 (finding that "once there has been a commercial offer, there can be no experimental use exception."); see also Pfaff v. Wells Elecs., Inc., 525 U.S. 55, 64 (1998) ("Nevertheless, an inventor who seeks to perfect his discovery may conduct extensive testing without losing his right to obtain a patent for his invention-even if such testing occurs in the public eye. The law has long recognized the distinction between inventions put to experimental use and products sold commercially.").

70. EZ Dock, Inc. v. Schafer Sys., Inc., 276 F.3d 1347, 1352 (Fed. Cir. 2002) ("Like evidence of experimentation sufficient to negate a bar, reduction to practice involves proof that an invention will work for its intended purpose.").

71. Id. at 1352 .

72. Honeywell Int'l, Inc. v. Universal Avionics Sys. Corp., 488 F.3d 982, 997 (Fed. Cir. 2007) (determining that a videotaped demonstration of an uncertified terrain warning system deployed in an experimental aircraft was experimental use even though the proof-of-concept demonstrations supported 
"documents show that the system was still in development at the time of the tests" even though the inventor "did not alter any specific part of [the] claimed system" following the experimentation. ${ }^{73}$ Contrarily, showing that prior to the critical date the patentee "in fact performed the patented method for a promise of future compensation" constitutes obvious proof that an invention is ready for patenting. ${ }^{74}$

Further, under the experimental use exception to the onsale bar, the patentee may engage in joint-research agreements or industry-development collaborations with the aim of reducing the invention to practice. ${ }^{75}$ These activities likely receive the benefit of the doubt because where multiple innovators cooperate in research and development they are more likely to bring the patented product to market. ${ }^{76}$ For instance, where an avionics-electronics developer attempted to partner with business- and regional-jet manufacturers to provide avionics electronics for their jets, the Federal Circuit found that a single proposal of commercial terms-contingent on successful flight testing-for supplying the avionics system did not vitiate a claim of experimental use. 77 The Federal Circuit acknowledged the district court's finding that "both projects involved experimental aircraft [and] uncertified equipment" 78 and noted that the avionics company "entered into these negotiations to facili-

commercial proposals).

73. Id.

74. Plumtree Software, Inc. v. Datamize, L.L.C., 473 F.3d 1152, 1162 (Fed. Cir. 2006) (noting that proof "that the contract itself required performance of the patented method" is not necessary).

75. C.R. Bard, Inc. v. M3 Sys., Inc., 157 F.3d 1340, 1356 (Fed. Cir. 1998) ("Generally cost defrayal arrangements between collaborators are not deemed to be invalidating sales, nor are payments for use substantially for test purposes.") The Federal Circuit noted that the public policy concerns underlying the statutory bar were muted in these instances because clinical tests and experimental sales " $d[0]$ not place the invention in the public domain or lead the public to believe that the device was freely available." Mahurkar v. Impra, Inc. (In re Mahurkar Double Lumen Hemodialysis Catheter Patent Litig.), 71 F.3d 1573, 1577 (Fed. Cir. 1995).

76. See generally Phillip W. Goter, Note, Princo, Patent Pools, and the Risk of Foreclosure: A Framework for Assessing Misuse, 96 IOWA L. REV. 699, 711-17 (2011) (discussing how standard-setting organizations, patent pools, and research joint ventures further public policy, competition, and consumer interests).

77. Honeywell, 488 F.3d at 996-97.

78. Id. at 996 (quoting Honeywell Int'l, Inc. v. Universal Avionic Sys. Corp., 343 F. Supp. 2d 272, 295 (D. Del. 2004)) (internal quotation marks omitted). 
tate its programs to test its new system with human pilots in a genuine cockpit setting . . . to determine that the invention worked for its intended purpose."79 In contrast, "[a]n offer to mass produce production models does not square with experimentation under any standard; it is commercial exploitation."80

\section{THE PUBLIC-USE BAR}

The public-use bar of $\S 102(b)$ denies patents to inventions that were "in public use . . in this country, more than one year prior to the date of the application for patent in the United States." ${ }^{1}$ As the Supreme Court has noted, "[Section] 102 of the Patent Act serves as a limiting provision, both excluding ideas that are in the public domain from patent protection and confining the duration of the monopoly to the statutory term." 82 Because "[c]ommercial exploitation of an invention as a trade secret violates the policies of encouraging an inventor's prompt disclosure and preventing the inventor's exploitation of an invention beyond the statutory patent term," the on-sale and public-use bars may function as a "tool that forces an inventor to choose between patent protection and trade secret protection." 83 For instance, in Metallizing Engineering Co. v. Kenyon Bearing $\&$ Auto Parts Co., where the patentee used its secret process to recondition worn parts for its customers, the Second Circuit noted "that it is a condition upon an inventor's right to a patent that he shall not exploit his discovery competitively after it is ready for patenting; he must content himself with either secrecy, or [a patent]." ${ }^{84}$ Among the other public policy interests in play, the public-use bar attempts to provide "inventors with a definite standard for determining when a patent application

79. Id. at 996. The Federal Circuit considered in its analysis that "Honeywell did not refer to the new system as ready for sale." Id. at 997.

80. Atlanta Attachment Co. v. Leggett \& Platt, Inc., 516 F.3d 1361, 1366 (Fed. Cir. 2008) (finding that a quotation for manufacture of 50 production units that according to the terms "became a contract with the signature of a purchasing entity ... constitute[d] an offer for sale that cannot avoid the onsale bar via the experimental use exception").

81. Patents, 35 U.S.C. $§ 102(b)$ (2006).

82. Pfaff v. Wells Elecs., 525 U.S. 55, 64 (1998).

83. Andrew S. Baluch, Note, Relating the Two Experimental Uses in Patent Law: Inventor's Negation and Infringer's Defense, 87 B.U. L. REV. 213, 225 (2007).

84. Metallizing Eng'g Co. v. Kenyon Bearing \& Auto Parts Co., 153 F.2d 516, 520 (2d Cir. 1946). 
must be filed." 85

In Egbert v. Lippman, the Supreme Court set out the "classical standard" for assessing public use of an apparatus. ${ }^{86}$ The inventor provided two corset springs for unrestricted, albeit concealed, use by a woman, who used them for more than two years before the inventor applied for a patent. ${ }^{87}$ While the inventor received no commercial advantage, the use was still public where the inventor gave or sold the invention "to another, to be used by the donee or vendee, without limitation or restriction, or injunction of secrecy." 88 The Federal Circuit extended the Pfaff two-prong analysis to public use in Invitrogen, requiring that the invention be ready for patenting and in "public use." 89 The invention is in public use when it is: "(1) accessible to the public; or (2) commercially exploited."90

\section{A. AcCessible to the Public}

Generally, "[a]n invention is in public use if it is shown to or used by an individual other than the inventor under no limitation, restriction, or obligation of confidentiality."91 Prior to the Supreme Court's decision in Pfaff, the Federal Circuit applied a totality-of-the-circumstances test to evaluate alleged

85. Weatherchem Corp. v. J.L. Clark, Inc., 163 F.3d 1326, 1333 (Fed. Cir. 1998) (quoting Pfaff, 525 U.S. at 65) (internal quotation marks omitted). Note that the on-sale bar functions similarly by allowing inventors to "explore [commercialization] of their invention before weighing the benefits of patent protection against the costs of obtaining the patent." Frank Albert, Note, Reformulating the On Sale Bar, 28 HASTINGS COMM. \& ENT L.J. 81, 101 (20052006).

86. Invitrogen Corp. v. Biocrest Mfg., L.P., 424 F.3d 1374, 1382 (Fed. Cir. 2005).

87. Egbert v. Lippman, 104 U.S. 333, 337 (1881).

88. Id. at 336 .

89. Invitrogen, 424 F.3d at 1379. The court considered that the Supreme Court "noted that both the 'on sale' and 'public use' bars were based on the same policy considerations[:] . . . 'reluctance to allow an inventor to remove existing knowledge from public use" and held that "[a] bar under $\S 102(\mathrm{~b})$ arises where, before the critical date, the invention is in public use and ready for patenting." Id. (quoting Pfaff, 525 U.S. at 64).

90. Am. Seating Co. v. USSC Grp., 514 F.3d 1262, 1267 (Fed. Cir. 2008) (quoting Invitrogen, 424 F.3d at 1380) (internal quotation marks omitted).

91. Id.; see also Adenta GmbH v. OrthoArm, Inc., 501 F.3d 1364, 1372 (Fed. Cir. 2007) (finding public use in displaying the invention at a trade show prior to the critical date); Eolas Techs. Inc. v. Microsoft Corp., 399 F.3d 1325, 1334 (Fed. Cir. 2005) (determining that a demonstration to two employees of an outside company without executed confidentiality agreements may constitute a public use "[b]ecause the [company's] employees were under no limitation, restriction or obligation of secrecy to [the inventor]"). 
public uses.92 Under that test, "[t]he totality of the circumstances is considered in conjunction with the policies underlying the public use bar" and includes:

[T] he nature of the activity that occurred in public; the public access to and knowledge of the public use; whether there was any confidentiality obligation imposed on persons who observed the use; whether persons other than the inventor performed the testing; the number of tests; the length of the test period in relation to tests of similar devices; and whether the inventor received payment for the testing. 93

In distancing itself from its earlier totality-of-thecircumstances test post-Pfaff, the Federal Circuit nonetheless identified several factors to consider when applying this test to determine public accessibility to the invention. ${ }^{94}$ For instance, a court may properly consider "the nature of the activity that occurred in public; public access to the use," 95 "confidentiality obligations imposed upon observers; . . . and the circumstances surrounding testing and experimentation." 96

Regarding confidentiality and control, the absence of an express, written confidentiality agreement is not dispositive, especially where an inventor controls and limits access to the invention to observers with whom the inventor has established a relationship because in those circumstances "an understanding of confidentiality can be implied."97 Likewise, where an in-

92. Sinskey v. Pharmacia Ophthalmics, Inc., 982 F.2d 494, 498 (Fed. Cir. 1992); see Pfaff, 525 U.S. at 67.

93. Netscape Commc'ns Corp. v. Konrad, 295 F.3d 1315, 1320 (Fed. Cir. 2002) ("There may be additional factors in a particular case relevant to the public nature of the use or any asserted experimental aspect.").

94. Invitrogen, 424 F.3d at 1380 (Fed. Cir. 2005).

95. Id.

96. Am. Seating Co. v. USSC Grp., 514 F.3d 1262, 1267 (Fed. Cir. 2008).

97. Id. at 1268. Compare Moleculon Research Corp. v. CBS, Inc., 793 F.2d 1261, 1265-66 (Fed. Cir. 1986) (finding that an inventor's private use and demonstrations to "a few close colleagues," including allowing his boss to use the invention in his presence, did not constitute public use because "the personal relationships and other surrounding circumstances were such that [the inventor] at all times retained control over [the invention's] use as well as over the distribution of information concerning it" and the inventor "never used the puzzle or permitted it[s] use[ ] in a place or at a time when he did not have a legitimate expectation of privacy and of confidentiality") with Beachcombers Int'l, Inc. v. WildeWood Creative Prods., Inc., 31 F.3d 1154, 1159-60 (Fed. Cir. 1994) (finding public use where the invention on display to between 20-30 guests at a party hosted by the inventor because the inventor "personally demonstrated the device to some of the guests for the purpose of getting feedback on the device;" and the inventor "made no efforts to conceal the device or keep anything about it secret. . . . [including] never ask[ing guests] to main- 
ventor disclosed his novel keyboard to "his business partner, a friend, potential investors, and a typing tester" but the keyboard was not configured to be used for its intended purpose (connected as an input device to a computer) except for a one time typing test [to assess typing speed], the invention was not found to be in public use. ${ }^{98}$ In reversing the district court on the issue of public use, the Federal Circuit looked to evidence that the typing tester had signed a non-disclosure agreement, that no record of continued use existed, and "[a]ll disclosures, except for the one-time typing test, only provided a visual view of the new keyboard design without any disclosure of the [actual invention]."99 Thus, the Federal Circuit found the "disclosures visually displayed the keyboard design without putting it into use" for its intended purpose. 100

When an inventor fails to either control or ensure confidentiality of its invention, public-use may be found "regardless of how little the public may have learned about the invention."101 In the context of an industry collaboration leading to an invention where non-inventor employees of one of the collaborators worked on developing the invention into a commercial system, such access may be considered public use-especially where the "access [to the invention] was not by an inventor and not protected by an obligation of secrecy to [the other industry collaborator]." 102 Similarly, use of a drilling method "at a commercial jobsite on public land on the side of an interstate highway" by those other than the inventor-and not under his control-is a public use, even if the claimed method was being performed outside of his control to test another invention (a drill bit) that the inventor did retain control of. 103

Equivalent to the on-sale bar, "an inventor's own prior

\footnotetext{
tain in secrecy any information about the device").

98. Motionless Keyboard Co. v. Microsoft Corp., 486 F.3d 1376, 1385 (Fed. Cir. 2007).

99. Id.

100. Id.

101. Metallizing Eng'g Co. v. Kenyon Bearing \& Auto Parts Co., 153 F.2d 516, 520 (2d Cir. 1946).

102. Bright Response, L.L.C. v. Google, Inc., 730 F. Supp. 2d 610, 617 (E.D. Tex. 2010).

103. New Railhead Mfg., L.L.C. v. Vermeer Mfg. Co., 298 F.3d 1290, 129798 (Fed. Cir. 2002) ("It is of crowning importance . . . that it was only the drill bit claimed in the ' 283 patent, and not the method of the ' 743 patent, that was being tested by [the inventor]. The method was successfully performed numerous times in January with the first prototype of the drill bit . . ..").
} 
commercial use, albeit kept secret, may constitute a public use or sale under $\S 102(\mathrm{~b})$, barring him from obtaining a patent."104 "However, when an asserted prior use is not that of the applicant, $\S 102(\mathrm{~b})$ is not a bar when that prior use or knowledge is not available to the public." 105 Also in common with the on-sale bar, the public-use bar requires that "the device used in public includes every limitation of the later claimed invention'... [even though] the public use itself need not be enabling." 106 Simply put, "the public use [must] relate[] to a device that embodied the invention."107 Thus, where a claimed invention is openly used by a third party, the patent of a later independent inventor will be invalid for public use-even though the use was of "high-level aspects" of the invention-because the public was already in possession of the invention. 108

Revisiting Metallizing Engineering Co., the seminal case on commercial exploitation of a process, Judge Learned Hand

104. Woodland Trust v. Flowertree Nursery, Inc., 148 F.3d 1368, 1370-71 (Fed. Cir. 1998) (citing Egbert v. Lippman, 104 U.S. 333, 336 (1881) (finding an "inventor's unobservable prior use was a public use") and TP Labs. v. Prof"l Positioners, Inc., 724 F.2d 965, 972 (Fed. Cir. 1984) (noting that "public use" may bar patentability "if the inventor is making commercial use of the invention under circumstances which preserve its secrecy" but finding no public use where a dentist installed an orthodontic invention in patients to test its efficacy, because "the dentist-patient relationship itself was tantamount to an express vow of secrecy")).

105. Id. at 1371 (citing W.L. Gore \& Assocs., Inc. v. Garlock, Inc., 721 F.2d 1540, 1550 (Fed. Cir. 1983)).

106. Zenith Elecs. Corp. v. PDI Commc'n Sys., Inc., 522 F.3d 1348, 1356 (Fed. Cir. 2008) (quoting Netscape Commc'ns Corp. v. Konrad, 295 F.3d 1315, 1321 (Fed. Cir. 2002)) (citing In re Epstein, 32 F.3d 1559, 1568 (Fed. Cir. 1994) (noting that "there is no requirement for an enablement-type inquiry")).

107. Id.; see also J.A. LaPorte, Inc. v. Norfolk Dredging Co., 787 F.2d 1577, 1583 (Fed. Cir. 1986) ("[T]he question is not whether the sale, even a third party sale, 'discloses' the invention at the time of the sale, but whether the sale relates to a device that embodies the invention.").

108. Lockwood v. Am. Airlines, Inc., 107 F.3d 1565, 1570 (Fed. Cir. 1997) ("[T]he public was aware that [a third party] possessed [the claimed multipleinstitution feature] and ... had been using [a system with that feature] to make travel reservations from independent travel agencies prior to [the inventor's] date of invention."); see also Elec. Storage Battery Co. v. Shimadzu, 307 U.S. 5, 20 (1939) (finding public use where a third-party prior inventor "continuously employed the alleged infringing machine and process for the production of lead oxide powder used in the manufacture of plates for storage batteries which have been sold in quantity" long before the independent inventor's filing date). "The ordinary use of a machine or the practise [sic] of a process in a factory in the usual course of producing articles for commercial purposes is a public use.” Elec. Storage Battery Co., 307 U.S. at 20. 
held that a patentee's secret use of a process to manufacture products for sale to the public triggered the public-use bar. ${ }^{109}$ The Federal Circuit endorsed Metallizing Engineering Co. in D.L. Auld Co. early on by invalidating a patent under the public-use bar where the patentee performed the claimed method to produce samples for prospective customers and provided at least one customer pricing and delivery quotes. ${ }^{110}$

\section{B. COMMERCIALly EXPLOITED}

The Federal Circuit has noted that "[c]ommercial exploitation is a clear indication of public use, but it likely requires more than . . . a secret offer for sale." 111 As a prong of the public-use bar, this commingling with the on-sale bar is unhelpful at best. When it comes to determining whether the invention was commercially exploited, the courts have provided scant guidance and quite circularly list "commercial exploitation" as an additional factor to consider alongside those indicative of public accessibility.

The relatively recent Invitrogen case was a missed opportunity to shed some light on the bounds of commercial exploitation as applied to the public-use bar. Instead, the opinion moved even closer to merging the public-use bar with the onsale bar. ${ }^{112}$ Prior to the critical date, Invitrogen used its claimed process in its own laboratories "to grow cells to be used in other projects within the company." 113 The district court be-

109. Metallizing Eng'g Co. v Kenyon Bearing \& Auto Parts Co., 153 F.2d 516, 520 (2d Cir. 1946) (distinguishing trade secrecy from the competitive wrong of effectively extending the patent term through delayed filing).

110. D.L. Auld Co. v. Chroma Graphics Corp., 714 F.2d 1144, 1148 (Fed. Cir. 1983) ("[A] party's placing of the product of a method invention on sale more than a year before that party's application filing date must act as a forfeiture of any right to the grant of a valid patent on the method to that party . ...").

111. Invitrogen Corp. v. Biocrest Mfg., L.P., 424 F.3d 1374, 1380 (Fed. Cir. 2005); see also Elec. Storage Battery, 307 U.S. at 19-20 ("A mere experimental use is not the public use defined by the Act, but a single use for profit, not purposely hidden, is such. The ordinary use of a machine or the practise [sic] of a process in a factory in the usual course of producing articles for commercial purposes is a public use.") (footnotes omitted).

112. See Invitrogen, 424 F.3d at 1383 ("[T]here is no evidence that Invitrogen received compensation for internally, and secretly, exploiting its cells. The fact that Invitrogen secretly used the cells internally to develop future products that were never sold, without more, is insufficient to create a public use bar to patentability.").

113. Id. 
lieved that Invitrogen intended this use "to further other projects beyond development of the claimed process . . . [in order] to acquire a commercial advantage" and found that the use did in fact "generate[] commercial benefits."114 The Federal Circuit, however, found no public use, accepting Invitrogen's argument that "this secret internal use was not 'public use' . . . because [Invitrogen] neither sold nor offered for sale the claimed process or any product derived from the process, nor did [Invitrogen] otherwise place into the public domain either the process or any product derived from it." 115 Thus, we are left with an illdefined spectrum of commercial exploitation requiring loose approximation between distinct, factually distant polesInvitrogen and Metallizing Engineering.

In support of its decision, the Invitrogen court referenced dicta from TP Laboratories, which "identif[ied] 'commercial exploitation' with sale of the [invention] or a charge for . . . use of the invention within the confidential confines of the company to generate commercial benefits." 116 The Federal Circuit distinguished dicta in Kinzenbaw v. Deere \& Co. that "commercial use trumps secrecy" and noted "that Kinzenbaw is consistent with the basic principle that a confidential use is not public under $\S 102(b)$ unless there is commercial exploitation."117 In Kinzenbaw, according to the Invitrogen court, John Deere's "widespread commercial exploitation of the invention was 'pub-

114. Id. (internal quotation marks omitted).

115. Id. Note that the Federal Circuit, as recently as 2002 (post-Pfaff), discussed the totality-of-the-circumstances approach employed by the district court. See Netscape Commc'ns Corp. v. Konrad 295 F.3d 1315, 1320 (Fed. Cir. 2002) ("The totality of the circumstances is considered in conjunction with the policies underlying the public use bar."). In Invitrogen, the Federal Circuit attempted to clarify its Netscape opinion by moving away from that approach but discusses factors to consider when evaluating the two prongs of the publicuse test. Invitrogen, 424 F.3d at 1380 ("The language in Netscape . . . should not be construed to resurrect a totality of the circumstances test . . . ."). It is unlikely that the small difference in practical application of the two tests is material to the Federal Circuit's decision.

116. Invitrogen, 424 F.3d at 1381-82 (citing TP Labs., Inc. v. Prof'l Positioners, Inc., 724 F.2d 965, 972-73 (Fed. Cir. 1984)) ("[A]n agreement of confidentiality, or circumstances creating a similar expectation of secrecy, may negate a 'public use' where there is not commercial exploitation.").

117. Id. at 1381 n.*(citing Kinzenbaw v. Deere \& Co., 741 F.2d 383, 390 (Fed. Cir. 1984)). The court also noted, "[a]s the Supreme Court pointed out in Pfaff . . . secrecy of use alone is not sufficient to show that existing knowledge has not been withdrawn from public use: commercial exploitation is also forbidden." Id. at 1382 . 
lic,"-not secret or confidential and so it does not help define commercial exploitation as a prong apart from public accessibility:

Deere's sales branch, acting through local independent dealers, made the invention available to farmers . . . for commercial use. Deere instructed the dealers to keep the units moving .... In 1973, the farmers used the planters for 1,000 hours in five states, and in 1974, for 500 hours in 11 states. By the end of 1974, 40,000 acres had been planted with the machines.... ${ }^{118}$

Discussing Invitrogen, one district court considered a very interesting set of facts involving an inventor's alleged public use through commercial exploitation of his trading-software invention. 119 The district court noted that in Invitrogen the claimed process was used to further other projects but the inventor "never commercialized the later patented process until after the critical date." 120 However, in the case before it, the inventor was alleged to have privately "used his inventive software for personal commercial gain prior to the critical date" by placing live trades in financial markets. ${ }^{121}$ Acknowledging that an inventor's private use of his invention is permissible, the court opined that an inventor's secret use of his invention to "trade for profit-to garner a competitive advantage in the marketplace - " may be commercial exploitation if those trades went beyond testing in a live market to ensure the system worked for its intended purpose. ${ }^{122}$

Revisiting Invitrogen and its discussion of Kinzenbaw, questions emerge as to what extent marketing efforts, apart from uncontrolled use by others, can be considered commercial exploitation. In Moleculon, the Federal Circuit found, in addition to no public accessibility, "absolutely no evidence . . . of commercially motivated activity by [the inventor]." 123 The court

118. Id. at 1381 n.* (quoting Kinzenbaw, 741 F.2d at 389-90).

119. Trading Techs. Int'l, Inc. v. eSpeed, Inc., 507 F. Supp. 2d 883, 898 (N.D. Ill. 2007) (denying both parties motions for summary judgment on the issue of public use due to disputed evidence regarding dates but commenting that "eSpeed may well have the better of the argument respecting public use").

120. Id. at 893 .

121. Id.

122. Id. at 893-97. As the litigation progressed, the public-use challenge became less important due to insufficient facts to prove it, and so the Federal Circuit unfortunately did not have a real opportunity to consider the commercial exploitation issue. Trading Techs. Int'l, Inc. v. eSpeed, Inc., 595 F.3d 1340, 1362 (Fed. Cir. 2010) (discussing the inventor's failure to disclose personal uses of the software before the critical date to the PTO).

123. Moleculon Research Corp. v. CBS, Inc., 793 F.2d 1261, 1265-66 (Fed. 
commented that "[d]iscussion between employer and employee does not by itself convert an employee's private pursuit into commercial enterprise with the employer." 124 Further, a simple inquiry into the process of submitting a puzzle to Parker Brothers' for consideration was not commercial exploitation. ${ }^{125}$ However, one district court has found that publishing an article in a scientific journal-touting the success of implanting the medical device invention and the subsequent benefit to patients-where there was "no indication from the article that the purpose of the implantations was experimental," likely rises to the level of commercial exploitation such that the invention was in public use. ${ }^{126}$

In sum, the question remains as to how directly coupled the challenged commercial activity must be to the claimed method. In both Metallizing and Plumtree, performance of the claimed method produced a product that could be marketed for sale. ${ }^{127}$ But, what about ancillary processes? Recall the example of a source-control and change-control system offered above. This system does not "produce" source code, but it does increase productivity and save the source-code developers time and development cost. Further, the use of such a system is undetectable by the public, and the system itself is not offered for sale to the public. However, the system "further[s] the institution's legitimate business objectives"128 and provides a competitive advantage-but isn't every action of a company performed for this purpose? Section 102(b) requires that the invention be in public use or on sale, and therefore a product that would not exist but for the claimed process should not invalidate that process, lest we stray too far down the slippery slope from the statutory text.

Cir. 1986) (quoting Moleculon Research Corp. v. CBS, Inc., 594 F. Supp. 1420, 1427 (D. Del. 1984)).

124. Id. at 1267 .

125. Id.

126. Arrow Int'l, Inc. v. Spire Biomedical, Inc., 635 F. Supp. 2d 46, 76-77 (D. Mass. 2009) (noting that the article "characterizes the procedures as tests to evaluate the new product's advantages and disadvantages").

127. See Plumtree Software, Inc. v. Datamize, L.L.C., 473 F.3d 1152, 1162 (Fed. Cir. 2006); Metallizing Eng'g Co. v Kenyon Bearing \& Auto Parts Co., 153 F.2d 516, 520 (2d Cir. 1946).

128. Madey v. Duke Univ., 307 F.3d 1351, 1362-63 (Fed. Cir. 2002) (explaining that this is especially true where the activity increases the institution's status or aids in talent acquisition). 


\section{THE EXPERIMENTAL-Use EXCEPTION}

The federal circuit clarified that "[t]he experimental use exception is not a doctrine separate or apart from the public use bar[;] . . . something that would otherwise be a public use may not be invalidating if it qualifies as an experimental use." ${ }^{29}$ In addition, experimental use also negates application of the on-sale bar. ${ }^{130}$ The Federal Circuit enumerated several factors that assist the determination of commercial uses versus "bona fide" experimentation, 131 including: (1) "necessity for public testing," (2) inventor retention of control over the experiment, (3) length of testing, (4) payment, (5) "whether there was a secrecy obligation," (6) identity of the person conducting the experiment, (7) "degree of commercial exploitation during testing," (8) "whether the inventor continually monitored the invention during testing," and (9) "the nature of contacts made with potential customers." 132 The "list is not exhaustive" and not all of the factors will apply in a particular case. ${ }^{133}$ Notice that commercial exploitation is among the factors, but here again, no meaningful definition emerges.

Inventor control and monitoring of the experimental use are important because "the experimental use exception only concerns the actions of the inventors and their agents." 134 Simi-

129. Clock Spring, L.P. v. Wrapmaster, Inc., 560 F.3d 1317, 1326 (Fed. Cir. 2009) (citations omitted); see generally, Andrew S. Baluch, Note, Relating the Two Experimental Uses in Patent Law: Inventor's Negation and Infringer's Defense, 87 B.U. L. REV. 213, 220-28 (2007) (providing a historical overview of the experimental use exception to the public-use bar).

130. See Electromotive Div. of Gen. Motors Corp. v. Transp. Sys. Div. of Gen. Elec. Co., 417 F.3d 1203, 1213 (Fed. Cir. 2005) (noting the factors "simply represent various kinds of evidence relevant to the question of whether precritical date activities involving the patented invention-either public use or sale were primarily experimental and not commercial"); infra Part II.A.

131. City of Elizabeth v. Am. Nicholson Pavement Co., 97 U.S. 126, 137 (1877) (noting that experimentation consists of a "bona fide effort to bring [an] invention to perfection, or to ascertain whether it will answer the purpose intended").

132. Allen Eng'g Corp. v. Bartell Indus., Inc., 299 F.3d 1336, 1353 (Fed. Cir. 2002) (quoting EZ Dock v. Schafer Sys., Inc., 276 F.3d 1347, 1357 (Fed. Cir. 2002) (Linn, J., concurring)). Other factors identified include "the nature of the invention, .... whether records of the experiment were kept, . . . whether the invention reasonably requires evaluation under actual conditions of use, . . . [and] whether testing was systematically performed." Id. (quoting EZ Dock, 276 F.3d at 1357).

133. Electromotive Div. of Gen. Motors Corp., 417 F.3d at 1213.

134. Atlanta Attachment Co. v. Leggett \& Platt, Inc., 516 F.3d 1361, 1366 (Fed. Cir. 2008). 
lar to its application in the public accessibility context, whether the inventor retains control over the experimental use may be dispositive in some instances, especially where an inventor claims a sale for experimental use but does not "perform the testing . . . [or] have control over the alleged testing."135 Additionally, an inventor's failure to maintain records related to testing of the invention weighs against a finding of experimental use. ${ }^{136}$

When considering the nature of contacts with potential customers and the nature of the payment for experimental use of an invention, notifying customers of the experimental nature of the product being sold is critical. Applying these factors, the court has noted that " $[\mathrm{w}]$ hether payment is made for the device is an important factual consideration, but the fact that a company paid for the use of patentee's device is not dispositive."137 However, "[i]f an inventor fails to communicate to a customer that the sale of the invention was made in pursuit of experimentation, then the customer, as well as the general public, can only view the sale as a normal commercial transaction." 138 Thus, as experimentation factors, control and customer awareness are "critical" and "ordinarily must be proven if experimentation is to be found." 139

Not on the list but critical nonetheless, the Federal Circuit has made clear "that experimental use cannot negate a public use when it is shown that the invention was reduced to practice before the experimental use." 140 As discussed in Part II.B, reduction to practice occurs at the point when an inventor "construct[s] an embodiment or perform[s] a process that [meets] all the limitations" and "determine[s] that the invention [will] work for its intended purpose." 141 Therefore, evidence of experimentation includes "tests needed to convince [an inventor] that the invention is capable of performing its intended purpose in

135. Id. ("While we have held that control may not be the lodestar test in all cases, we have also said that it is important, and sometimes dispositive.").

136. Netscape Commc'ns Corp. v. Konrad, 295 F.3d 1315, 1321-22 (Fed. Cir. 2002).

137. Monon Corp. v. Stoughton Trailers, Inc., 239 F.3d 1253, 1260 (Fed. Cir. 2001); see also Atlanta Attachment Co., 516 F.3d at 1365.

138. Electromotive Div. of Gen. Motors Corp., 417 F.3d at 1214.

139. Id. at $14-15$.

140. In re Omeprazole Patent Litig., 536 F.3d 1361, 1372 (Fed. Cir. 2008).

141. Id. at 1373 . 
its intended environment." 142 Obviously, "[t]esting is required to demonstrate reduction to practice in some instances because without such testing there cannot be sufficient certainty that the invention will work for its intended purpose."143 As a final qualification, the Federal Circuit recently noted that "there is no experimental use unless claimed features or overall workability are being tested for purposes of the filing of a patent application." 144

Even though experimental use generally cannot negate a public use where the invention was reduced to practice before the experimental use in question, a district court found no public use where experimentation occurred after reduction to practice. ${ }^{145}$ In this case, field testing was used to debug and evaluate the patented system. ${ }^{146}$ The inventors continued to modify the system based on experiment results and the version used in field trials was not the final version of the invention. ${ }^{147}$ The district court cited Invitrogen for the proposition that "[e]vidence that the researchers were still conducting experiments of the . . - prototype is relevant in determining the precise nature of the activity that occurred in public" even though the invention had already been reduced to practice. ${ }^{148}$ The district court further noted other evidence of "openly experimental" use. First, researchers were required to get approval from the university's research oversight committee in order to use human drivers as test subjects during the field trials. ${ }^{149}$ Further, even though the details of the experimentation were not apparent to the test drivers, the drivers understood that "the nature of the endeavor in which they were participating was clearly experimental and [they] would not ... justifiably [] believe the invention was available to the public."150 Additionally, the court noted that "[t]he inventors never showed the drivers how the Back Seat

142. Gould, Inc. v. United States, 579 F.2d 571, 583 (Ct. Cl. 1978).

143. In re Omeprazole, 536 F.3d at 1373 (quoting Cooper v. Goldfarb, 154 F.3d 1321, 1327 (Fed. Cir. 1998)) (internal quotation marks omitted).

144. Clock Spring, L.P. v. Wrapmaster, Inc., 560 F.3d 1317, 1327 (Fed. Cir. 2009).

145. Mass. Inst. of Tech. v. Harman Int'l Indus., 584 F. Supp. 2d 297, 311 (D. Mass. 2008).

146. Id. at $302-03$.

147. $I d$.

148. Id. at 311 (citing Invitrogen Corp. v. Biocrest Mfg., L.P., 424 F.3d

1374, 1380 (Fed. Cir. 2005)).

149. Id. at 312 .

150. Id. 
Driver system worked, and the drivers were exposed to the workings of the system only to the extent that it was necessary to test it." 151 Finally, the public, viewing the prototype vehicle from the street, was unable to see that the test drivers were using the Back Seat Driver system. ${ }^{152}$

Experimentation to resolve potential issues with commercialization of the invention is not covered under the experimental-use exception. ${ }^{153}$ This raises an interesting issue when the invention requires regulatory approval prior to commercial marketing because the invention must be used sufficiently to determine its safety and efficacy-the use creating public knowledge of the invention and fueling market demand for the product. 154 In Omeprazole, the Federal Circuit considered whether a pharmaceutical was reduced to practice prior to Phase III clinical trials. ${ }^{155}$ In determining that the clinical trials constituted experimental use, the Federal Circuit noted that in vivo testing as part of the clinical trials was necessary to proving the formulation worked for its intended purpose even though the inventors suspected their formulation would be successful based on laboratory testing. ${ }^{156}$ Revisiting Honeywell, which also required regulatory approval of its avionics invention, even publicizing experimentation with an invention does not vitiate the claimed experimental use.157 The Federal Circuit affirmed that Honeywell's demonstrations to the aviation industry were experimental even though they "did not always relate to claimed features" because all of the demonstrations involved the invention's intended use as an in-flight

\footnotetext{
151. Id. at 313 .

152. $I d$.

153. See Cygnus Telecomms. Tech., L.L.C. v. Telesys Commc'ns, L.L.C. (In re Cygnus Telecomms. Tech., L.L.C.. Patent Litig.), 536 F.3d 1343, 1355 (Fed. Cir. 2008) (rejecting the inventor's testimony that the invention was not ready for patenting because it "would not scale for commercial use").

154. See Honeywell Int'l, Inc. v. Universal Avionics Sys. Corp., 488 F.3d 982, 998 (Fed. Cir. 2007) ("Although these [test] flights allowed contact with potential customers, there is no evidence that they were solely or primarily for marketing purposes.").

155. In re Omeprazole Patent Litig., 536 F.3d 1361, 1372 (upholding the district court's factual finding that "the claimed formulation was not reduced to practice before the clinical trials were completed ....").

156. Id. at $1373-74$.

157. Honeywell Int'l, 488 F.3d at 998 (finding that even though a "reporter published an article ... about [the test] flight ... he indicated the system was still under development”). See infra Part II.B.
} 
avionics system. 158

Regarding sales incident to experimentation, "[t]he law has long recognized a distinction between experimental usage and commercial exploitation of an invention." 159 "Any attempt to use [an invention] for a profit, and not by way of experiment ... deprive[s] the inventor of his right to a patent" when that use occurs prior to the critical date. ${ }^{160}$ However, an inventor may charge another for their experimental use of his invention. ${ }^{161}$ In such instances the determining question is "whether the primary purpose of the offers and sales was to conduct experimentation." 162 In other words, sales during the experimental phase must be "merely incidental to the primary purpose of experimentation." 163 The Federal Circuit often looks to the amount of payment for the invention relative to the product's later market price. ${ }^{164}$ In allowing sales and contact with potential customers during experimentation, the Federal Circuit has noted that "[c]ommercial purpose underlies virtually every contact between inventor and potential customer" and so customer contact for purposes of experimentation "does not convert an otherwise experimental purpose into a public use."165 However,

158. Id. (noting that testing is permitted "to determine the workability of an invention even if the claims do not expressly set forth the intended use under examination").

159. Atlanta Attachment Co. v. Leggett \& Platt, Inc., 516 F.3d 1361, 1365 (Fed. Cir. 2008)

160. City of Elizabeth v. Am. Nicholson Pavement Co., 97 U.S. 126, 137 (1877); see also Allied Colloids Inc. v. Am. Cyanamid Co., 64 F.3d 1570, 1576 (Fed. Cir. 1995) ("[T] tests were for the benefit of the patentee, and thus contravenes the inference of public use for or by the potential customer.").

161. See, e.g., Allen Eng'g Corp. v. Bartell Indus., Inc., 299 F.3d 1336, 1353-54 (Fed. Cir. 2002).

162. Atlanta Attachment Co., 516 F.3d at 1365; see also TP Labs. Inc. v. Prof'l Positioners, Inc., 724 F.2d 965, 972 (Fed. Cir. 1984) (noting that some other factors, such as "expression by an inventor of his subjective intent to experiment," particularly after institution of litigation, are not very helpful).

163. Paragon Podiatry Lab., Inc. v. KLM Labs., Inc., 984 F.2d 1182, 1185 (Fed. Cir. 1993). The court attempted to clarify the issue: "There are not, however, two separable issues, i.e., 'Was the invention on sale?' and then, 'Was the sale an experimental use?' The correct statement of the sole issue is 'Was the invention on sale within the meaning of section 102(b)?"' Id. at 1185 n.3.

164. See Mark Levy, An Analysis of the On Sale Bar and Its Impact on the Structure and Negotiation of Development Agreements, 30 U. DAYTON L. REV. 181, 198 (2004) ("A sale for full price may be viewed as a bar rather than as an experimental use.").

165. Allied Colloids Inc., 64 F.3d at 1575; see also Paragon Podiatry Lab., Inc., 984 F.2d at 1188 (finding sales limited to low volume purchases "may be 
"experimentation conducted to determine whether the invention would suit a particular customer's purposes does not fall within the experimental use exception."166

\section{CONCLUSION}

As Learned Hand noted, "it is a condition upon an inventor's right to a patent that he shall not exploit his discovery competitively after it is ready for patenting; he must content himself with either secrecy, or legal monopoly."167 This language reflects the public policy interest underlying the commercial exploitation prong of the public-use bar. As it stands though-and as this Article aims to demonstrate-the Federal Circuit's jurisprudence does little more than allow one to compare their (or a client's) practices of interest to those the Federal Circuit has found (usually in dicta) to constitute commercial exploitation. Recall in Woodlands Trust, the Federal Circuit upheld the patent, but commented that the use of an irrigation system by a commercial greenhouse for more than a year prior to the critical date could constitute commercial exploitation (assuming evidence of sufficient weight, not before the court). ${ }^{168}$ Similarly, in D.L. Auld, the Federal Circuit invalidated a method claim because the patentee had offered to sell-prior to the critical date-a device manufactured using the patented method. ${ }^{169}$ Another circumstance that emerges is failure to notify customers of the experimental nature of the product being provided. ${ }^{170}$ And, of course, "[a]n offer to mass produce produc-

relevant to determining whether the scope of the inventor's testing was appropriate but only where other evidence indicates that the sales were restricted and controlled as appropriate for experimental use").

166. Atlanta Attachment Co., 516 F.3d at 1366; see also Paragon Podiatry Lab., Inc., 984 F.2d at 1188 (finding that because "Paragon represented to doctors and their patients that the [devices] were fully tested" the experimental use did not apply and the invention was considered on sale). In rejecting gauging customer satisfaction with an invention through sales, the Federal Circuit noted that "there [is] no reason to be concerned about customer relations if the [experimental] devices prove[] unsatisfactory" and determined that marketing testing of the invention is not included in the experimental use exception. $I d$.

167. Metallizing Eng'g Co. v. Kenyon Bearing \& Auto Parts Co., 153 F.2d 516, 520 (2d Cir. 1946).

168. Woodland Trust v. Flowertree Nursery, Inc., 148 F.3d 1368, 1370 (Fed. Cir. 1998).

169. D.L. Auld Co. v. Chroma Graphics Corp., 714 F.2d 1144, 1151 (Fed. Cir. 1983).

170. Electromotive Div. of Gen. Motors Corp. v. Transp. Sys. Div. of Gen. 
tion models does not square with experimentation under any standard; it is commercial exploitation." 171

So where does that leave commercial exploitation when the case law revolves around a sale of the invention or a disclosure to the public? Or in the experimental use context, where the primary purpose of a sale must be for experimentation, but experimentation may include commercial promotion so long as the experimentation is not primarily for marketing purposes? Commercial exploitation has to be more than a "magic trump card" discretionarily used to discipline inventors that cross an invisible line. ${ }^{172}$ Perhaps a more certain (better) approach would be for the Federal Circuit to define commercial exploitation, or at least catalogue its "approved" list of factors that inform the commercial exploitation determination. Given the public policy concerns embodied in the $\S 102(b)$ statutory bar, it is unlikely that commercial exploitation should require that the invention be on sale or even that a revenue stream can be directly traced to an inventor's use of the invention.

However, in the same way that the on-sale bar currently has vitiated the commercial exploitation analysis under the public-use bar, we must be careful to not vitiate the on-sale bar through our definition. Thus, commercial exploitation concerns under the public-use bar should be most acute in the context of pre-sale marketing activities. Suppose a university laboratory, in an effort to find a corporate sponsor through technology transfer, invites several industry players to individually attend demonstrations of its ready-for-patenting invention. Even though the demonstrations are not experimental and all confidentiality and invention-control criteria have been met, the systematic demonstrations objectively prove a purpose of commercial exploitation and should implicate the public-use bar. Considering that the inventors can simply apply for a patent to protect themselves, a definition of commercial exploitation that includes such targeted pre-sale marketing activities is not dra-

Elec. Co., 417 F.3d 1203, 1214-15 (Fed. Cir. 2005).

171. Atlanta Attachment Co., 516 F.3d at 1366 (Fed. Cir. 2008); see also Elec. Storage Battery Co. v. Shimadzu, 307 U.S. 5, 20 (1939) ("The ordinary use of a machine or the practise [sic] of a process in a factory in the usual course of producing articles for commercial purposes is a public use.").

172. See Cass R. Sunstein, Foreword: Leaving Things Undecided, 110 HARV. L. REV. 4, 61 (1996) (discussing the Supreme Court's failure to articulate their actual standard of scrutiny and instead using "rationality review, traditionally little more than a rubber stamp ... to invalidate badly motivated laws"). 
conian and furthers the public-policy interests embodied in the public-use bar. What more is required such that the test for commercially exploitative public use is distinct from the on-sale bar? Courts offer little in the way of a definition and are in danger of conflating the two separate bars. Perhaps they simply know commercial exploitation when they see it. ${ }^{173}$ Regardless, the Federal Circuit should endeavor to demarcate the bounds of commercial exploitation as soon as the opportunity presents itself and in so doing provide much needed guidance to innovators, practitioners, and the district courts.

173. See Jacobellis v. Ohio, 378 U.S. 184, 197 (1964) (Stewart, J., concurring) (struggling to define a workable standard for obscenity that does not degenerate into case-by-case review of the material and facts by appellate courts, duplicating the efforts of trial courts). 